Section Editors

David C. Spencer, MD

Steven Karceski, MD

David C. Tong, MD, FAHA, FAAN

\section{Statins and stroke}

It is well known that drugs that bring down the bad cholesterol in the blood (statins) can reduce the risk of a second heart attack after a first heart attack occurs. We do not know whether this is also true for stroke. Heart attacks happen when the heart muscle does not get enough blood and oxygen because of a blocked blood vessel. A similar problem happens with stroke, when blood vessels to the brain are blocked. Therefore, it is reasonable to think that statins may help prevent second strokes as well.

Until recently, there was little information about whether statins can reduce stroke risk. Lately, one new study ${ }^{1}$ did test this question and found that the risk of a second stroke after a first one was lowered by statins. However, it is not clear whether this is only true of the statin that was tested, or if it is an effect that can be seen with all statins.

WHAT DID THE AUTHORS STUDY? In a study in this issue of Neurology ${ }^{\circledR}$, the records of 794 first-time stroke patients were reviewed. ${ }^{2}$ Records for all of these patients tracked what happened to them over the next 10 years. The study team carefully recorded all of their test results and all of their risk factors for stroke such as smoking and high blood pressure. All patients had experienced a stroke, and it was up to their doctor at the time to decide whether or not they would be treated with a statin. The choice of which statin to use was also made by each patient's doctor. The people who got statins after a stroke were compared with those who did not.

WHAT DO THE RESULTS SHOW? The use of statins reduced the risk of a second stroke by about half (16.3\% vs $7.5 \%)$. The risk of death was much lower in the group treated with statins. It did not seem to matter which statin patients took. Statins all work in the liver to reduce cholesterol levels in the body.
They also have other effects not directly related to cholesterol, such as reducing inflammation. While there are some differences between statins, the study seems to suggest that any of the various medications in this class can show this positive effect. Some common statins are atorvastatin, fluvastatin, pravastatin, rosuvastatin, and simvastatin. They may have different brand names.

Importantly, the lower risk of stroke seemed to be maintained for as long as the statin was taken. This study also showed that the good effect of a statin did not depend on the amount of bad fat in the blood. Even people who did not have very high cholesterol measurements seemed to benefit.

WHY IS THIS INFORMATION HELPFUL? This information is helpful in telling us that statins can reduce stroke risk after a stroke has occurred. If you have had a stroke, you should ask your doctor if you should take a statin. If you do take a statin already, you should continue to take it for as long as possible to reduce the risk of another stroke.

The next step is to learn how statins reduce stroke risk. It seems that this is more than just reducing the bad fat in the blood, but exactly how it works is still not clear. We also need to know whether some people do better with the treatment than others so we can make better choices about who and when someone should get the drug.

\section{REFERENCES}

1. Amarenco P, Bogousslavsky J, Callahan A 3rd, et al. Highdose atorvastatin after stroke or transient ischemic attack. N Engl J Med 2006;355:549-559.

2. Milionis HJ, Giannopoulos S, Kosmidou M, et al. Statin therapy after first stroke reduces 10-year stroke recurrence and improves survival. Neurology 2009;72:1816-1822.

3. The Stroke Collaborative. Available at: http://www. giveme5forstroke.org/ Accessed April 17, 2009. 
Section Editors

David C. Spencer, MD

Steven Karceski, MD

\section{About stroke}

Adapted from: Leonard AD, Brey RL. Blood pressure control and stroke: An ounce of prevention is worth a pound of cure. Neurology 2002;59:E1-E2

WHAT IS STROKE? A stroke, or brain attack, is caused by the sudden loss of blood flow to the brain or bleeding inside the head. A stroke can cause brain cells to die. This damage can cause paralysis, speech problems, loss of feeling, memory and reasoning problems, coma, and possibly death. Fortunately, there are effective ways to prevent stroke. If you have a stroke, seeking immediate medical attention can help reduce your chances of death and disability.

WHAT ARE THE WARNING SIGNS OF STROKE? The "Give Me 5" uses easy-to-remember words to help identify the five signs of stroke?:

- Walk-is their balance off?

- Talk -is their speech slurred or face droopy?

- Reach-is one side weak or numb?

- See-is their vision all or partly lost?

- Feel—is their headache severe?

HOW COMMON IS STROKE? Every year, about 780,000 people in the United States suffer a stroke and about 160,000 die. Stroke is the nation's number three killer after heart disease and cancer. Stroke is the number one cause of adult disability.

Stroke Is an Emergency. Call 911 immediately if you or someone you know experiences any of the above warning signs. Jot down the time the symptoms started. Sometimes these warning signs last for only a few minutes and then stop. But, even if that happens or if you feel better, call 911 for help.

\section{RISK FACTORS FOR STROKE THAT CAN BE TREATED OR CHANGED}

- High blood pressure

- Atrial fibrillation (an irregular heart beat)

- Diabetes

- Cigarette smoking

- Hyperlipidemia (high fat level in the blood)

- Alcohol abuse

- Obesity

- Sickle cell disease

WHAT CAUSES A STROKE? There are two types of stroke or brain attack. Ischemic stroke is caused by an interruption of blood flow to the brain. Hemorrhagic stroke is caused by bleeding inside the brain.
About $85 \%$ of all strokes are ischemic. Ischemic stroke can be caused by narrowing of the large arteries to the brain, also known as atherosclerosis. If a clot forms in the neck vessels, pieces can break off and block a brain blood vessel. Clots may also form in the heart and travel by blood flow to the brain vessels, where they become lodged.

Hemorrhagic stroke is caused by the bursting of a blood vessel in the brain. It accounts for about $15 \%$ of strokes. Subarachnoid hemorrhage occurs when there are weak spots on brain arteries (aneurysms) that burst and cover the brain with blood. Blood vessels in the brain can also burst if they are weakened by high blood pressure, diabetes, and aging.

WHAT ARE THE TREATMENTS FOR STROKE? Immediate medical care is critical for the person who is having a stroke or brain attack. New treatments work only if given within a few hours after the onset of a stroke. For example, a clot-busting drug must be given within 3 hours of stroke onset.

HOW IS STROKE PREVENTED? Some risk factors-age, sex, race, and a history of stroke in the family - cannot be changed. However, many others can be controlled. Most controllable risk factors relate to the health of the heart and blood vessels. The following can help prevent stroke:

- Having regular medical checkups

- Controlling high blood pressure

- Not smoking; stopping if you do

- Treating heart disease, especially an irregular heart beat called atrial fibrillation

- Improving diet: avoid excess fat, salt, and alcohol

- Exercising

- Controlling diabetes

- Seeking immediate medical attention for warning signs of stroke

\section{FOR MORE INFORMATION}

American Stroke Association

www.strokeassociation.org

National Institute of Neurological Disorders and Stroke http://www.ninds.nih.gov/disorders/stroke/stroke.htm

National Stroke Association

http://www.stroke.org/site/PageNavigator/HOME

Centers for Disease Control and Prevention

http://www.cdc.gov/stroke/

The Internet Stroke Center

http://www.strokecenter.org/patients/index.html 


\title{
Neurology
}

\author{
Statins and stroke \\ David C. Tong \\ Neurology 2009;72; e112-e113 \\ DOI 10.1212/WNL.0b013e3181a9fad1
}

This information is current as of May 26, 2009

\author{
Updated Information \& \\ Services \\ Supplementary Material \\ References \\ Permissions \& Licensing \\ Reprints
}

including high resolution figures, can be found at: http://n.neurology.org/content/72/21/e112.full

Supplementary material can be found at: http://n.neurology.org/content/supp1/2009/11/05/72.21.e112.DC1

This article cites 2 articles, 1 of which you can access for free at: http://n.neurology.org/content/72/21/e112.full\#ref-list-1

Information about reproducing this article in parts (figures,tables) or in its entirety can be found online at:

http://www.neurology.org/about/about_the_journal\#permissions

Information about ordering reprints can be found online:

http://n.neurology.org/subscribers/advertise

Neurology ${ }^{\circledR}$ is the official journal of the American Academy of Neurology. Published continuously since 1951, it is now a weekly with 48 issues per year. Copyright . All rights reserved. Print ISSN: 0028-3878. Online ISSN: 1526-632X.

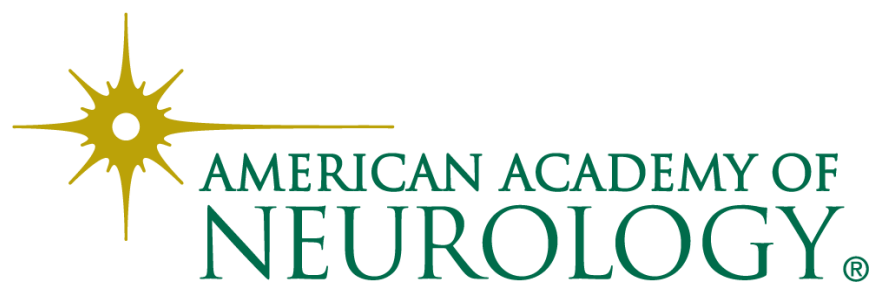

